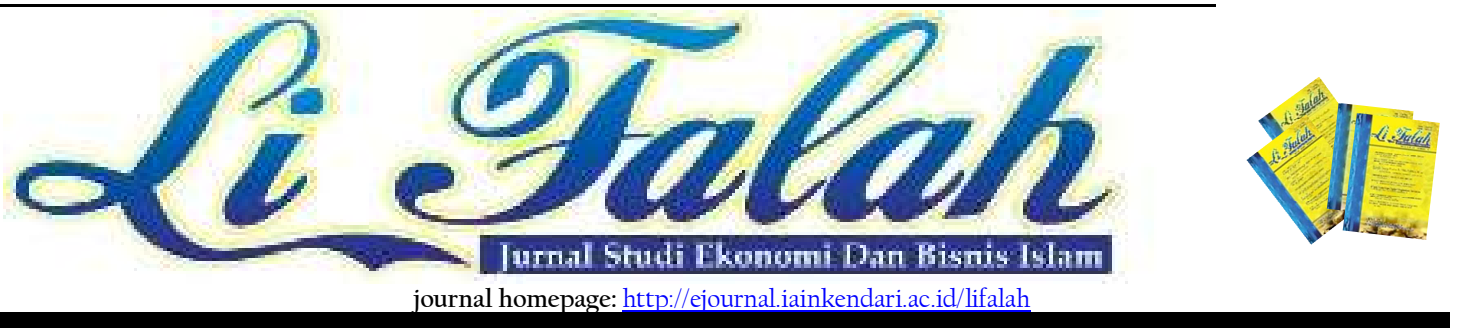

\title{
Niat Mengonsumsi Makanan dan Minuman Halal Pada Remaja
}

\author{
Alvien Nur Amalia
}

STIE Indonesia Banking School

Email: alvien.amalia@ibs.ac.id

\section{INFO ARTIKEL \\ Keywords: niat mengkonsumsi, label halal, presepsi harga, dan keputusan pembelian konsumen.}

DOI: http://dx.doi.org/10.31332/lifalah.v5il.1787 \begin{abstract}
A B S T R A C T
Penelitian ini bertujuan untuk menguji faktorfaktor yang mempengaruhi niat mengonsumsi makanan dan minuman halal pada remaja. Data yang digunakan adalah data primer hasil kuesioner yang disebar kepada para remaja dengan rentang usia 16-24 tahun yang berada di Jakarta, Bogor, Depok, Tangerang dan Bekasi. Responden dalam penelitian ini berjumlah 100 oarang dan di analisis dengan SmartPLS 3.0. Pendekatan Theory of Planned Behaviour (TPB) digunakan dalam menentukan variabel-variabel penelitian. Hasil penelitian ini menunjukkan bahwa variabel subjectives norms memengaruhi niat untuk mengonsumsi makanan dan minuman halal pada remaja.
\end{abstract}

\section{Pendahuluan}

Pemuda merupakan investasi suatu bangsa yang seharusnya memiliki kemampuan fisik, keterampilan, dan intelektual yang kuat (Malau dan Simanjutak, 2017). Pemuda menurut World Health Organization (WHO) memounyai rentang usia yang cukup besar yaitu antara usia 18 tahun sampai dengan 65 tahun (Hosking, 2018). Namun, dalam rentang usia tersebut, Badan
Kependudukan dan Keluarga Berencana (BKKBN) lebih spesifik menjelaskan bahwa seseorang yang belum menikah dan menpunyai mempunyai umur dalam rentang angka 10 sampai 24 tahun merupakan usia remaja. Karakteristik kelompok ini salah satunya adalah memiliki rasa ingin tahu yang besar akan suatu hal (www.depkes.go.id). Salah satu contoh kota terbesar di Indonesia adalah Jakarta, dimana merupakan keuntungan di 
masa mendatang apabila Jakarta dapat menjadikan kelompok mudanya menjadi seseorang yang baik. Pada tahun 2015 Jakarta mempunyai jumlah penduduk kelompok remaja sebesar 2.321.076 jiwa atau hampir 23 persen dari total penduduk Jakarta (jakarta.bps.go.id).

Dikisahkan pada berbagai surat dalam Al Quran tentang remaja yang bertaqwa antara lain (dakwatuna.com):

a. Surat Maryam ayat 15 dikisahkan Nabi Yahya muda semenjak kecil telah dikaruniai hikmah dan kebijaksanaan.

b. Surat Yusuf ayat 22 dikisahkan tentang Nabi Yusuf sejak masa mudanya menjadi pejuang kebenaran.

c. Surat Ash-Shaffat ayat 102-107 berkisah tentang Nabi Ismail muda yang mempunyai ketaqwaan tinggi yaitu meyakini perintah Allah dan taat pada ketentuan-Nya.

Menjadi remaja yang baik berarti menjadi remaja yang bertaqwa seperti kisah-kisah di atas. Salah satu contoh tindakan yang dapat dilakukan oleh para remaja adalah cermat dalam mengkonsumsi suatu barang, yaitu terkait dengan halal atau tidaknya barang tersebut untuk dikonsumsi (Yuswohady, 2014).

Indonesia sebagai negara muslim terbesar di dunia saat ini sedang mengembangkan industry halal karena potensinya yang besar. Tahun 2016 industri halal di Indonesia, khususnya sektor makanan halal, perjalanan, pakaian, dan obat-obatan serta kosmetik halal telah menguasai pangsa pasar dunia sekitar 11 persen (www.bi.go.id).

Suatu Industri dikatakan halal apabila mampu menerapkan nilai-nilai Islam seperti kejujuran, keadilan dan kemanunggalan (ukhuwah) dalam bisnisnya. Nilai-nilai ini dapat diterapkan pada setiap aktivitas bisnis yang meliputi produksi, penjualan dan pengambilan keuntungan. 
Tabel 1 Penerapan Nilai-Nilai Islam dalam Bisnis

\begin{tabular}{|l|l|l|}
\hline Nilai & Aktivitas Bisnis & Makna Nilai \\
\hline \multirow{4}{*}{ Kejujuran } & Produksi & Produk yang halal dan baik \\
\cline { 2 - 3 } & Penjualan & Informasi Produl Terbuka \\
\cline { 2 - 3 } & $\begin{array}{l}\text { Pengambilan } \\
\text { Keuntungan }\end{array}$ & Bebas dan Konsisten \\
\hline \multirow{5}{*}{ Keadilan } & Produksi & Produk untuk Kemaslahatan \\
\cline { 2 - 3 } & Penjualan & Martabat Hidup \\
\cline { 2 - 3 } $\begin{array}{l}\text { Kemanunggalan } \\
\text { (Ukhuwah) }\end{array}$ & $\begin{array}{l}\text { Pengambilan } \\
\text { Keuntungan }\end{array}$ & Kebutuhan Pokok Maslahat \\
\cline { 2 - 3 } & Produksi & $\begin{array}{l}\text { Kebutuhan } \\
\text { Kemaslahatan Hidup }\end{array}$ \\
\cline { 2 - 3 } & $\begin{array}{l}\text { Penjualan } \\
\text { Sengambilan } \\
\text { Keuntungan }\end{array}$ & $\begin{array}{l}\text { Sesuai kemampuan pelanggan dan } \\
\text { Harmonisasi }\end{array}$ \\
\hline
\end{tabular}

Sumber: Fordebi \& Adesy, 2016

\section{Sesuai tuntunan Alquran} diantaranya surat $\mathrm{Al}$ Baqarah ayat 168 dan Al Maidah ayat 88, seorang muslim harus mengkonsumsi seluruh makanan yang halal dan baik. Suatu makanan dikategorikan halal apabila memenuhi syarat tertentu. Syarat tersebut terdapat dalam Al quran yang menjelaskan tentang makanan halal antara lain:

1. Surat Al Baqarah ayat 173 yang artinya “ Sesungguhnya Allah hanya mengharamkan bagimu bangkai, darah, daging babi, dan binatang yang disembelih dengan menyebut nama selain Allah.”

2. Surat Al Baqarah ayat 219 yang artinya "Mereka bertanya kepadamu tentang khamar dan judi. Katakanlah: "Pada keduanya terdapat dosa yang besar dan beberapa manfaat bagi manusia, tetapi dosa keduanya lebih besar dari manfaatnya". Dan mereka bertanya kepadamu apa yang mereka nafkahkan. Katakanlah: "Yang lebih dari keperluan". Demikianlah Allah menerangkan ayat-ayat-Nya kepadamu supaya kamu berfikir,

3. Al Maidah ayat 3 yang artinya "Diharamkan bagimu (memakan) bangkai, darah, daging babi, (daging hewan) yang disembelih atas nama selain Allah, yang tercekik, yang terpukul, yang jatuh, yang ditanduk, dan diterkam binatang buas, kecuali yang sempat kamu menyembelihnya, dan (diharamkan bagimu) yang disembelih untuk berhala."

Di Indonesia, kehalalan dari suatu produk makanan yang diproduksi oleh perusahaan ditentukan oleh suatu lembaga yaitu Lembaga Pengkajian Pangan, Obat- 
obatan, dan Kosmetika Majelis Ulama Indonesia (LPPOM MUI). Perusahaan yang bergerak dalam industri pengolahan (pangan, obat, kosmetika), Rumah Potong Hewan (RPH), restoran, katering, dapur dapat mendaftarkan sertifikasi halal ke LPPOM MUI. Adapun sertifikat halalnya kemudian akan diterbitkan oleh Badan Penyelenggara Jaminan Produk Halal (BPJPH).

Adapun niat untuk mengonsumsi produk halal baik berupa makanan, minuman maupun kosmetik dipengaruhi beberapa faktor pembentuk. Faktor pembentuk utama pada umumnya sama sedangan teori perilaku terencana (TPB) yang meliputi sikap (attitude), norma subyektif (subjective norms) dan kontrol perilaku yang dirasakan (perceived behavioral control). Selain tiga faktor tersebut, terdapat juga beberapa faktor tambahan meliputi relijusitas, pengetahuan, kewajiban moral dan kepercayaan, serta pengetahuan produk (Vanany, Soon, Maryani, Wibawa, 2019; Briliana dan Mursito, 2017; Khalek dan Ismail, 2015; Rochmanto dan Widiyanto 2015).

Berdasarkan beberapa surat dalam Al-Quran dijelaskan bahwa mengonsumsi makanan dan minuman halal wajib hukumnya bagi seorang muslim. Terkait dengan hal tersebut, remaja dengan perilaku rasa ingin tahu yang besar dan ingin lepas dari aturan mempounyai potensi untuk melanggar aturan agama. Sehingga perlu dilakukan penelitian tentang faktor-faktor yang mempengaruhi niat mengonsumsi makanan dan minuman halal pada remaja. Berdasarkan hal tersebut, maka pertanyaan penelitian yang diajukan adalah:

1. Apakah attitude memengaruhi niat mengonsumsi makanan dan minuman halal pada remaja?

2. Apakah subjective norms memengaruhi niat mengonsumsi makanan dan minuman halal pada remaja?

3. Apakah perceived behavioral control memengaruhi niat mengonsumsi makanan dan minuman halal pada remaja?

\section{Tinjauan Pustaka}

2.1 Niat

Niat dalam KBBI merupakan "kehendak (keinginan dalam hati) akan melakukan sesuatu" (www.kbbi.web.id). Lebih lanjut niat berperilaku dalam Teori perilaku terencana (TPB) yang di prakarsai oleh Ajzen menyebutkan bahwa terdapat beberapa faktor pembentuknya antara lain (Vanany, 2019 et. al):

1. Attitude; merupakan sikap seseorang

2. Subjective Norms; merupakan pengaruh dari luar diri seseorang.

3. Perceived Behavioral Control; merupakan kendali diri dimana sesorang dapat dengan percaya diri melakukan suatu hal. 
Ketiga faktor tersebut di atas juga menjadi pembentuk. Hal tersebut dapat dilihat pada Tabel 2.1 berikut:

dipengaruhi beberapa indikator yang

Tabel 2 Indikator Pembentuk Faktor

\begin{tabular}{|c|c|}
\hline Faktor & Indikator \\
\hline \multirow[t]{5}{*}{ Attitude } & Mengkonsumsi makanan \& minuman halal. \\
\hline & $\begin{array}{l}\text { Saya percaya saya bisa mengkonsumsi makanan \& } \\
\text { minuman halal dibandingkan dengan makanan } \& \text { minuman } \\
\text { non-halal. }\end{array}$ \\
\hline & $\begin{array}{l}\text { Makanan \& minuman halal lebih bersih dibandingkan } \\
\text { dengan makanan \& minuman non-halal }\end{array}$ \\
\hline & $\begin{array}{l}\text { Makanan \& minuman halal lebih aman untuk dikonsumsi } \\
\text { dibandingkan dengan makanan \& } \text { minuman non-halal }\end{array}$ \\
\hline & $\begin{array}{l}\text { Makanan \& minuman halal lebih sehat untuk dikonsumsi } \\
\text { dibandingkan dengan makanan \& } \& \text { minuman non-halal }\end{array}$ \\
\hline \multirow{4}{*}{ Subjective Norms } & $\begin{array}{l}\text { Sebagian besar orang yang penting bagi hidup saya memilih } \\
\text { mengkonsumsi makanan \& } \text { minuman halal }\end{array}$ \\
\hline & $\begin{array}{l}\text { Anggota keluarga saya memilih mengkonsumsi makanan } \& \\
\text { minuman halal }\end{array}$ \\
\hline & $\begin{array}{l}\text { Orang lain bisa memengaruhi saya untuk mengkonsumsi } \\
\text { makanan \& minuman halal }\end{array}$ \\
\hline & $\begin{array}{l}\text { Teman saya berfikir bahwa saya sebaiknya mengkonsumsi } \\
\text { makanan \& minuman halal }\end{array}$ \\
\hline \multirow{5}{*}{$\begin{array}{c}\text { Perceived } \\
\text { Behavioral } \\
\text { Control }\end{array}$} & $\begin{array}{l}\text { Sangat mudah untuk menemukan makanan \& minuman } \\
\text { halal di Indonesia. }\end{array}$ \\
\hline & $\begin{array}{l}\text { Sangat mudah untuk menemukan makanan } \& \text { minuman } \\
\text { halal di kampus/sekolah saya. }\end{array}$ \\
\hline & $\begin{array}{l}\text { Saya mempunyai kesempatan untuk mengkonsumsi } \\
\text { makanan \& minuman halal. }\end{array}$ \\
\hline & $\begin{array}{l}\text { Ada banyak pilihan makanan \& minuman halal di } \\
\text { kampus/sekolah saya. }\end{array}$ \\
\hline & Harga makanan \& minuman halal terjangkau. \\
\hline \multirow{7}{*}{$\begin{array}{l}\text { Behavioral } \\
\text { Intention }\end{array}$} & $\begin{array}{l}\text { Saya tidak akan makan \& minum jika makanan } \& \\
\text { minumannya tidak halal. }\end{array}$ \\
\hline & $\begin{array}{l}\text { Saya tidak akan makan \& minum jika makanan \& minuman } \\
\text { diragukan halal. }\end{array}$ \\
\hline & $\begin{array}{l}\text { Saya hanya akan makan } \& \text { minum pada tempat yang } \\
\text { menjual makanan } \& \text { minuman halal. }\end{array}$ \\
\hline & $\begin{array}{l}\text { Saya hanya akan mengkonsumsi makanan \& minuman } \\
\text { halal. }\end{array}$ \\
\hline & $\begin{array}{l}\text { Saya akan memastikan bahwa yang saya konsumsi } \\
\text { makanan \& minuman halal. }\end{array}$ \\
\hline & $\begin{array}{l}\text { Sebelum saya membeli, saya akan memastikan bahwa } \\
\text { makanan \& minuman tersebut halal. }\end{array}$ \\
\hline & $\begin{array}{l}\text { Saya tidak akan mengkonsumsi makanan \& minuman jika } \\
\text { disiapkan menggunakan bahan non-halal misalnya alkohol. }\end{array}$ \\
\hline
\end{tabular}

Sumber: Khalek dan Ismail, 2015 


\subsection{Remaja}

Remaja merupakan masa peralihan dari anak menjadi dewasa. Rentang usia definisi remaja ini bervariasi tergantung dari budaya dan tujuan penggunaannya. Penelitian tentang kesehatan reproduksi remaja di Indonesia mengartikan remaja merupakan orang muda yang mempunyai usia 15 sampai dengan 24 tahun. BKKBN mendefinisikan remaja adalah seseorang yang mempunyai rentang usia 10-24 tahun, sedangkan, Departemen Kesehatan dengan rentang usia 10-19 tahun (www.depkes.go.id). Pada remaja terjadi perubahan hormonal, fisik, psikologis maupun sosial yang berlangsung secara sekuensial. Secara psikososial, pertumbuhan pada masa remaja (adolescent) dibagi dalam 3 tahap yaitu (Batubara, 2010):

1. Early, terjadi pada usia 12 sampai dengan 14 tahun. Selain terdapat pertumbuhan fisik yang cepat, remaja pada masa ini cenderung mempunyai krisis identitas dan jiwa yang labil.

2. Middle, terjadi pada usia 15 samapai 17 tahun. Pada masa ini, remaja cenderung memperhatikan penampilan fisik dirinya dan mulai sering bersedih (moody).

3. Late adolescent, terjadi pada usia 18 tahun. Pada masa ini, remaja mulai menemukan jati dirinya sehingga ide- ide dalam dirinya terus berkembang dan mempunyai emosi yang cenderung stabil.

\subsection{Makanan dan Minuman Halal}

Arti halal menurut KBBI adalah hal yang diizinkan (tidak dilarang) oleh syarak atau hukum Islam. Halal pada konsumsi makanan dan minuman ini berarti makanan dan minuman yang akan di konsumsi diperbolehkan oleh hukum Islam. adapun makanan dan minuman yang halal meliputi (www.halalmuibali.or.id):

1. Halal secara zatnya

2. Halal cara memprosesnya

3. Halal cara memperolehnya, dan

4. Minuman yang tidak halal

Dalam Al quran yang menjelaskan tentang makanan halal antara lain:

a. Surat $\mathrm{Al}$ Baqarah ayat 173 yang artinya "Sesungguhnya Allah hanya mengharamkan bagimu bangkai, darah, daging babi, dan binatang yang disembelih dengan menyebut nama selain Allah."

b. Surat Al Baqarah ayat 219 yang artinya "Mereka bertanya kepadamu tentang khamar dan judi. Katakanlah: "Pada keduanya terdapat dosa yang besar dan beberapa manfaat bagi manusia, tetapi dosa keduanya lebih besar dari manfaatnya". Dan mereka bertanya kepadamu apa yang mereka nafkahkan. Katakanlah: "Yang lebih dari keperluan". Demikianlah Allah menerangkan ayat-ayat-Nya kepadamu supaya kamu berfikir, 
c. Al Maidah ayat 3 yang artinya "Diharamkan bagimu (memakan) bangkai, darah, daging babi, (daging hewan) yang disembelih atas nama selain Allah, yang tercekik, yang terpukul, yang jatuh, yang ditanduk, dan diterkam binatang buas, kecuali yang sempat kamu menyembelihnya, dan (diharamkan bagimu) yang disembelih untuk berhala."

\subsection{Penelitian Terdahulu}

Vanany et. al (2019) melakukan penelitian yang mempunyai tujuan untuk menyelidiki faktor-faktor yang mempengaruhi konsumsi,makanan halal konsumen dengan menggunakan model teori perilaku terencana (TPB) yang diperluas. Responden yang digunakan sebesar 418 konsumen di Surabaya dan diolah menggunakan analisis regresi berganda. Hasil penelitian berhasil memperluas faktor yang berpengaruh dalam TPB antara lain: kesadaran yang dirasakan, kebiasaan, identitas diri religius (RSI), kewajiban moral dan kepercayaan untuk menentukan niat konsumen dalam makanan halal konsumsi. Sikap, RSI, dan kewajiban moral merupakan prediktor signifikan dari niat untuk mengonsumsi makanan halal.

$$
\text { Briliana dan Mursito (2017) }
$$

melakukan penelitian dengan tujuan memberikan pemahaman yang lebih baik tentang faktor-faktor yang berpengaruh pada sikap menuju produk kosmetik halal. Responden yang digunakan sebesar 350 orang dan dianalisis menggunakan SmartPLS 2.0. Hasil penelitian menunjukkan bahwa sikap terhadap produk kosmetik halal adalah anteseden penting dari niat untuk membeli produk kosmetik halal dan memediasi pengaruh pengetahuan, religiusitas dan norma subyektif.

Khalek dan Ismail (2015) melakukan penelitian yang mempunyai tujuan untuk menguji faktor-faktor penentu niat Generasi Y dalam mengkonsumsi makanan halal di Malaysia. Terdapat tiga variabel yang digunakan dalam menentukan niat yaitu sikap, norma subyektif dan kontrol perilaku yang dirasakan sesuai dengan Teori Perilaku Terencana (TPB) Ajzen. Responden yang digunakan 425 di di Klang Valley Malaysia dan data diolah menggunakan korelasi melalui SPSS. Hasil penelitian ini menunjukka bahwa niat Generasi Y dalam mengonsumsi makanan halal dipengaruhi sikap, norma subyektif dan kontrol perilaku yang dirasakan terhadap makanan halal.

Rochmanto dan Widiyanto (2015) melakukan penelitian dengan tujuan untuk menganalisis dan memberikan bukti empiris apakah pengetahuan produk dan norma agama berpengaruh positif terhadap 
sikap konsumen dalam niat mengkonsumsi produk makanan dan minuman halal di Semarang. Data dari 200 responden dikumpulkan dengan metode purposive sampling dan dianalisis menggunakan SPSS versi 2l. Hasil penelitian ini menunjukkan bahwa pengetahuan produk norma agama dan sikap konsumen terhadap produk halal berpengaruh positif dan signifikan terhadap niat mengkonsumsi produk makanan dan minuman halal.

Berdasarkan uraian di atas maka dibentuk hipotesa sebagai berikut:

a. Hipotesis l yaitu attitude memengaruhi niat mengonsumsi makanan dan minuman halal pada remaja.

b. Hipotesis 2 yaitu subjective norms memengaruhi niat mengonsumsi makanan dan minuman halal pada remaja.

c. Hipotesis 3 yaitu perceived behavioral control memengaruhi niat mengonsumsi makanan dan minuman halal pada remaja.

\section{Metode Penelitian}

Penelitian ini menggunakan metode survei dengan menyebar kuesioner kepada sampel yang ada. Pemilihan sampel menggunakan metode purposive sampling, yaitu memilih sampel berdasarkan kelompok, wilayah atau sekelompok individu melalui pertimbangan tertentu yang diyakini mewakili semua unit analisis yang ada. Kuesioner akan disebar ke remaja yang berumur dari 16 tahun sampai dengan 24 tahun di Jakarta dan sekitarnya yang meliputi Bogor, Depok, Tangerang dan Bekasi karena berdasarkan tinjauan pustaka paling relevan untuk dijadikan sampel penelitian. Data hasil survei akan diolah dengan bantuan program SmartPLS 3.0. karena bertujuan untul memprediksi selain itu ketepatan predikti tinggi (Haryono, 2017).

Variabel dalam penelitian ini terdiri dari variabel eksogen dan endogen dengan beberapa indicator pembentuk faktor. 
Tabel 3 Indikator Pembentuk Faktor

\begin{tabular}{|c|c|}
\hline \multirow{2}{*}{\multicolumn{2}{|c|}{$\begin{array}{ll}\text { Indikator } \\
\end{array}$}} \\
\hline & \\
\hline \multirow{5}{*}{$\begin{array}{c}\text { Attitude } \\
\text { (variabel eksogen) }\end{array}$} & Mengkonsumsi makanan \& minuman halal. \\
\hline & $\begin{array}{l}\text { Saya percaya saya bisa mengkonsumsi makanan } \& \\
\text { minuman halal dibandingkan dengan makanan } \& \text { minuman } \\
\text { non-halal. }\end{array}$ \\
\hline & $\begin{array}{l}\text { Makanan \& minuman halal lebih bersih dibandingkan } \\
\text { dengan makanan \& minuman non-halal }\end{array}$ \\
\hline & $\begin{array}{l}\text { Makanan \& minuman halal lebih aman untuk dikonsumsi } \\
\text { dibandingkan dengan makanan \& } \& \text { minuman non-halal }\end{array}$ \\
\hline & $\begin{array}{l}\text { Makanan \& minuman halal lebih sehat untuk dikonsumsi } \\
\text { dibandingkan dengan makanan \& minuman non-halal }\end{array}$ \\
\hline \multirow{4}{*}{$\begin{array}{l}\text { Subjective Norms } \\
\text { (variabel eksogen) }\end{array}$} & $\begin{array}{l}\text { Sebagian besar orang yang penting bagi hidup saya memilih } \\
\text { mengkonsumsi makanan \& minuman halal }\end{array}$ \\
\hline & $\begin{array}{l}\text { Anggota keluarga saya memilih mengkonsumsi makanan } \& \\
\text { minuman halal }\end{array}$ \\
\hline & $\begin{array}{l}\text { Orang lain bisa memengaruhi saya untuk mengkonsumsi } \\
\text { makanan \& minuman halal }\end{array}$ \\
\hline & $\begin{array}{l}\text { Teman saya berfikir bahwa saya sebaiknya mengkonsumsi } \\
\text { makanan \& minuman halal }\end{array}$ \\
\hline \multirow{5}{*}{$\begin{array}{c}\text { Perceived } \\
\text { Behavioral } \\
\text { Control } \\
\text { (variabel eksogen) }\end{array}$} & $\begin{array}{l}\text { Sangat mudah untuk menemukan makanan } \& \text { minuman } \\
\text { halal di Indonesia. }\end{array}$ \\
\hline & $\begin{array}{l}\text { Sangat mudah untuk menemukan makanan \& minuman } \\
\text { halal di kampus/sekolah saya. }\end{array}$ \\
\hline & $\begin{array}{l}\text { Saya mempunyai kesempatan untuk mengkonsumsi } \\
\text { makanan \& minuman halal. }\end{array}$ \\
\hline & $\begin{array}{l}\text { Ada banyak pilihan makanan \& minuman halal di } \\
\text { kampus/sekolah saya. }\end{array}$ \\
\hline & Harga makanan \& minuman halal terjangkau. \\
\hline \multirow{7}{*}{$\begin{array}{l}\text { Behavioral } \\
\text { Intention } \\
\text { (variabel } \\
\text { endogen) }\end{array}$} & $\begin{array}{l}\text { Saya tidak akan makan \& minum jika makanan } \& \\
\text { minumannya tidak halal. }\end{array}$ \\
\hline & $\begin{array}{l}\text { Saya tidak akan makan \& minum jika makanan \& minuman } \\
\text { diragukan halal. }\end{array}$ \\
\hline & $\begin{array}{l}\text { Saya hanya akan makan \& minum pada tempat yang } \\
\text { menjual makanan } \& \text { minuman halal. }\end{array}$ \\
\hline & $\begin{array}{l}\text { Saya hanya akan mengkonsumsi makanan \& minuman } \\
\text { halal. }\end{array}$ \\
\hline & $\begin{array}{l}\text { Saya akan memastikan bahwa yang saya konsumsi } \\
\text { makanan \& minuman halal. }\end{array}$ \\
\hline & $\begin{array}{l}\text { Sebelum saya membeli, saya akan memastikan bahwa } \\
\text { makanan \& minuman tersebut halal. }\end{array}$ \\
\hline & $\begin{array}{l}\text { Saya tidak akan mengkonsumsi makanan \& minuman jika } \\
\text { disiapkan menggunakan bahan non-halal misalnya alkohol. }\end{array}$ \\
\hline
\end{tabular}

Sumber: Khalek dan Ismail, 2015 
Adapun bentuk umum dari model

SmartPLS yang nanati akan dihasilkan:

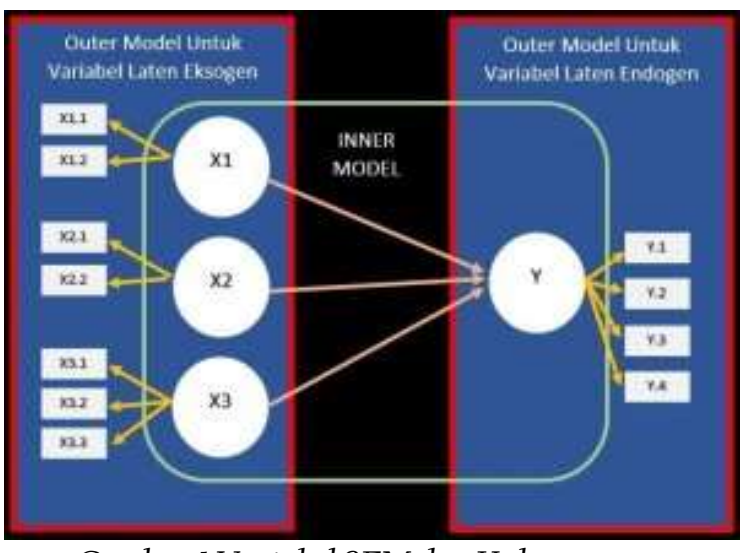

Gambar 1 Variabel SEM dan Hubungannya

Sumber: www.statistikian.com

Berdasarkan Gambar di atas maka

penelitian ini merupakan model

pengukuran formatif dimana dalam model ini ada beberapa hal yang perlu dicermati (Haryono, 2017):

1. Tidak memerlukan pengujian validitas tersendiri

2. Nilai estimasi harus signifikan dapat dilakukan dengan bootstrapping.

3. Harus bebas dari multikolineraritas, dilihat dari nilai VIF tidak boleh lebih besar 10 .

Ada beberapa evaluasi yang diperlukan yaitu:

1. Evaluasi outer model variabel behavioral intention

2. Evaluasi outer model variabel attitude, subjective norms dan perceived behavioral control.

3. Uji multikolinearitas

4. Evaluasi inner model

\section{Hasil dan Pembahasan}

Dalam bab ini akan dijelaskan tentang analisis dan pembahasan dari hasil kuesioner yang telah diolah, sehingga sebagai awalannya akan dibahas tentang gambaran umum objek penelitian. Selanjutnya dilakukan analisis data sampel dengan pendekatan SmartPLS, sehingga akan diperoleh kesimpulan tentang faktorfaktor yang mempengaruhi niat mengonsumsi makanan dan minuman halal pada remaja.

\subsection{Profil Responden}

Total kuesioner yang masuk sebanyak 203 responden, akan tetapi tidak semua kuesioner tersebut dijadikan sampel, karena Smart-PLS hanya dapat mengolah sebanyak 100 data. Oleh karena itu total kuesioner yang dapat dijadikan sampel penelitian adalah 100 responden 
yang diharapkan mewakili tujuan penelitian ini terlihat dalam Tabel 4.1 penelitian. berikut:

Adapun karakteristik dari responden yang di gunakan dalam

Tabel 4 Karakteristik Responden

\begin{tabular}{|c|c|c|}
\hline Karakteristik & Uraian & Jumlah (Orang) \\
\hline \multirow{2}{*}{ Jenis Kelamin } & Laki-laki & 50 \\
\hline & Perempuan & 50 \\
\hline \multirow{8}{*}{ Usia } & 17 Tahun & 31 \\
\hline & 18 Tahun & 32 \\
\hline & 19 Tahun & 14 \\
\hline & 20 Tahun & 5 \\
\hline & 21 Tahun & 7 \\
\hline & 22 Tahun & 7 \\
\hline & 23 Tahun & 1 \\
\hline & 24 Tahun & 3 \\
\hline \multirow{3}{*}{ Pendidikan (saat ini) } & $\begin{array}{l}\text { Kuliah di Perguruan } \\
\text { Tinggi Negeri }\end{array}$ & 4 \\
\hline & $\begin{array}{l}\text { Kuliah di Perguruan } \\
\text { Tinggi Swasta }\end{array}$ & 28 \\
\hline & $\begin{array}{lr}\text { Siswa/i di } \\
\text { SMA/SMK/MA/sederajat }\end{array}$ & 68 \\
\hline \multirow{5}{*}{ Tempat Tinggal } & Jakarta & 26 \\
\hline & Bogor & 64 \\
\hline & Depok & 5 \\
\hline & Tangerang & 1 \\
\hline & Bekasi & 4 \\
\hline
\end{tabular}

Berdasarkan Tabel 4 di atas, akan dibahas tiap-tiap karakteristik sebagai berikut:

a. Jenis Kelamin. Berdasarkan Tabel 4 di atas jumlah responden yang berjenis kelamin laki-laki dan perempuan masing-masing sebanyak 50 orang atau sebesar 50 persen.

b. Usia. Kelompok usia 18 tahun sebgai responden terbanyak dalam penelitian ini dengan 32 orang, sedangkan kelompok usia 23 tahun merupakan kelompok terkecil dengan jumlah respon hanya 1 orang dari total responden.

c. Pendidikan (saat ini). Karakteristik pendidikan saat ini dalam penelitian ini dibedakan menjadi tiga kelompok, yaitu responden yang sedang kuliah di perguruan tinggi negeri, kuliah di perguruan tinggi swasta dan siswa/i di SMA/SMK/MA/sederajat. 
Berdasarkan Tabel 4.1, respondon yang sedang kuliah di perguruan tinggi negeri sebanyak 4 persen. Responden responden yang sedang kuliah di perguruan tinggi swasta sebanyak 28 persen, Dan, respon terbanyak adalah siswa/i di SMA/SMK/MA/sederajat 68 persen.

d. Tempat Tinggal. Sebagian besar responden penelitian yang berpartisipasi dalam penelitian ini bertempat tinggal di Bogor dan Jakarta. Sebagian kecil lainnya bertempat tinggal di Depok, Bekasi dan Tangerang.

\subsection{Hasil Analisis Data}

Hasil pengolahan dengan Smart PLS dapat dilihat pada Gambar 4.1 berikut:

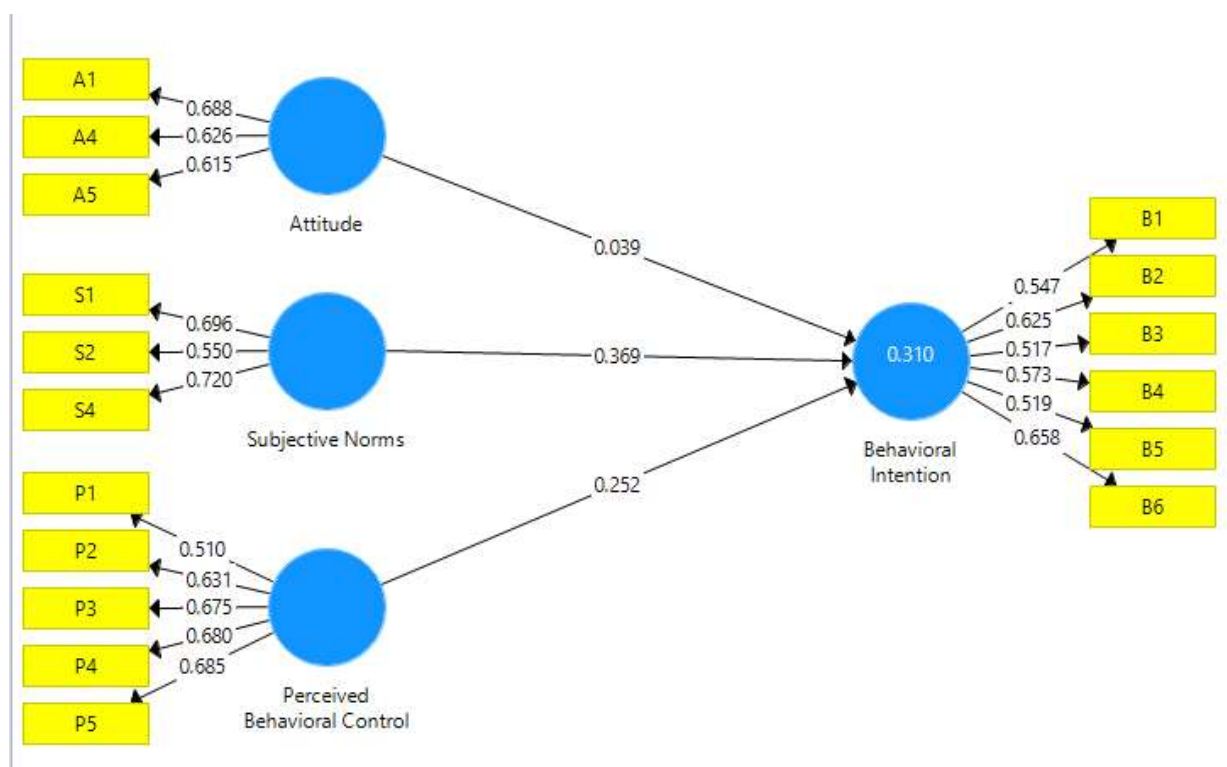

Gambar 2 Hasil PLS Algoritm

\subsubsection{Evaluasi Outer Model Variabel Behavioral Intention}

Pada evaluasi variabel behavioral Intention ini dilakukan secara reflektif terhadap indicator-indikator penelitian.
Hasil pengujian pertama ada beberapa indicator yang mumpanyai nilai loading faktor dibawah 0,4 atau mempunyai $\mathrm{p}$ value dibawah 0,05 sehingga harus dihapus dari pengamatan. 
Tabel 5 Indikator-Indikator yang dihapus dari Pengamatan

\begin{tabular}{|l|l|}
\hline A2 & $\begin{array}{l}\text { Saya percaya saya bisa mengkonsumsi makanan \& minuman halal } \\
\text { dibandingkan dengan makanan \& minuman non-halal }\end{array}$ \\
\hline A3 & $\begin{array}{l}\text { Makanan \& } \text { minuman halal lebih bersih dibandingkan dengan makanan } \\
\text { \& minuman non-halal }\end{array}$ \\
\hline S3 & $\begin{array}{l}\text { Orang lain bisa memengaruhi saya untuk mengkonsumsi makanan \& } \\
\text { minuman halal }\end{array}$ \\
\hline B7 & $\begin{array}{l}\text { Saya tidak akan mengkonsumsi makanan \& minuman jika disiapkan } \\
\text { menggunakan bahan non-halal misalnya alkohol. }\end{array}$ \\
\hline
\end{tabular}

Pada pengujian kedua, hasil PLS

Bootstrapping dapat dilihat pada Tabel 6

berikut:

\section{Outer Loadings}

\section{Tabel 6 Hasil Outer Loading PLS Bootstrapping}

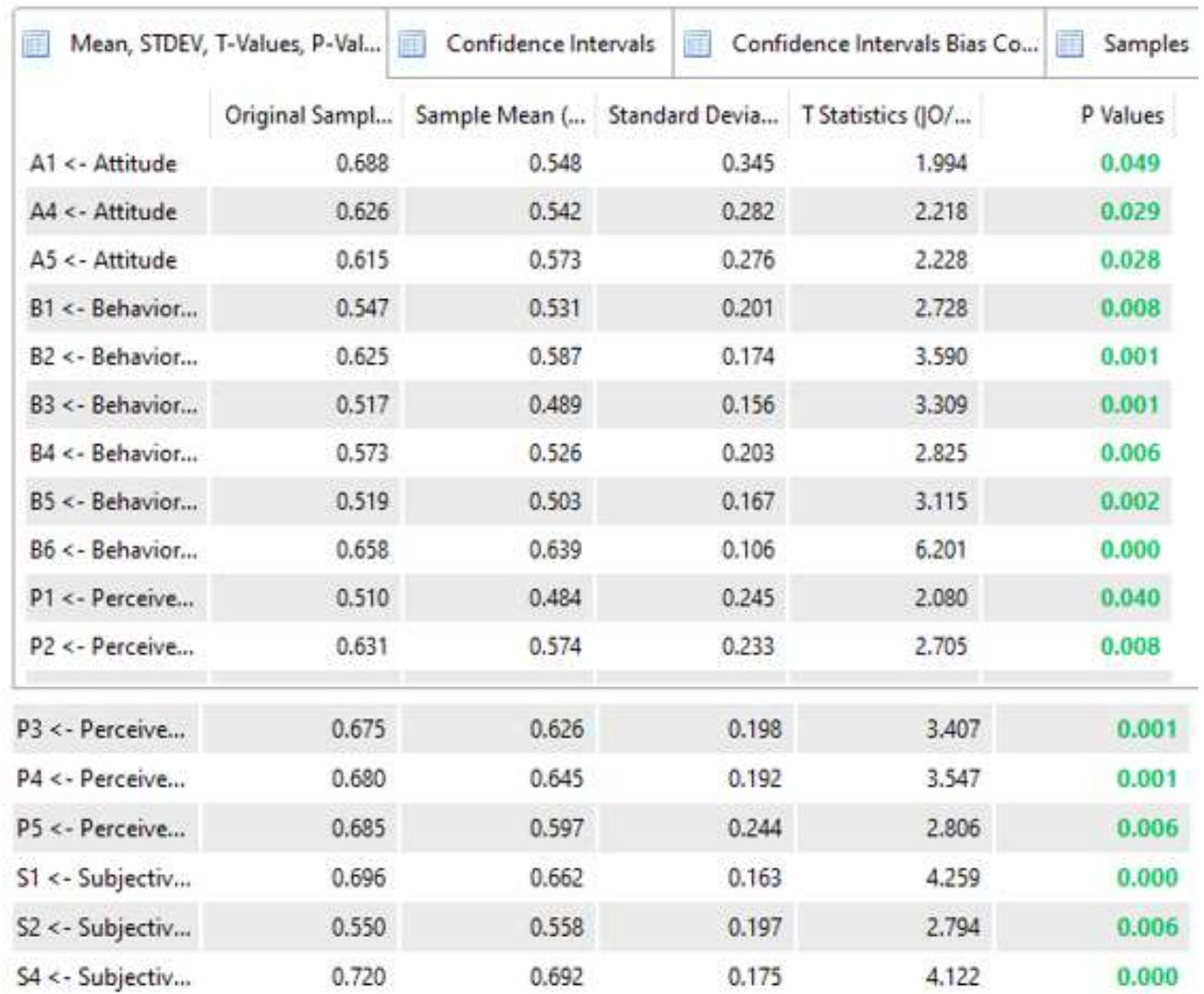

Berdasarkan Tabel 6 di atas

diketahui bahwa seluruh nilai loading factor pada kolom original sample memenuhi syarat yaitu lebih besar sama dengan 0,4 . Selain itu seluruh nilai $\mathrm{p}$-value juga lebih kecil dari 0,05.

\subsubsection{Evaluasi Outer Model Variabel Attitude, Subjective Norms dan Perceived Behavioral Control.}

Pengujian ini dilakukan melalui hubungan formatif semua indikator dengan variabel-variabel Attitude, Subjective Norms dan Perceived Behavioral 
Control. Adapun hasil pengujian tersebut

dapat dilihat pada Tabel 4.4 berikut:

Outer Weights

\section{Tabel 7 Koefisien Regresi pada Outer Weight}

\begin{tabular}{|c|c|c|c|c|c|c|}
\hline \multirow[t]{2}{*}{ Mean, STDEV, } & T-Values, P-Val... & \multicolumn{2}{|c|}{ Confidence Intervals } & \multicolumn{2}{|c|}{ Confidence Intervals Bias Co... } & \multirow{2}{*}{$\begin{array}{l}\text { Samples } \\
\text { P Values }\end{array}$} \\
\hline & Original Sampl... & Sample Mean (... & Stand & ard Devia... & TStatistics $00 / \ldots$ & \\
\hline A1 <- Attitude & 0.599 & 0.469 & & 0.350 & 1.710 & 0.090 \\
\hline A4 <- Attitude & 0.471 & 0.420 & & 0.263 & 1.788 & 0.077 \\
\hline A5 <- Attitude & 0.476 & 0.449 & & 0.268 & 1.775 & 0.079 \\
\hline B1 <- Behavior... & 0.219 & 0.236 & & 0.119 & 1.838 & 0.069 \\
\hline$B 2<-$ Behavior... & 0.268 & 0.254 & & 0.093 & 2.868 & 0.005 \\
\hline B3 <- Behavior... & 0.297 & 0.268 & & 0.104 & 2.851 & 0.005 \\
\hline B4<- Behavior... & 0.376 & 0.324 & & 0.144 & 2.612 & 0.010 \\
\hline B5 <- Behavior... & 0.287 & 0.271 & & 0.163 & 1.754 & 0.083 \\
\hline B6 <- Behavior... & 0.296 & 0.287 & & 0.080 & 3.716 & 0.000 \\
\hline P1 <- Perceive... & 0.139 & 0.143 & & 0.170 & 0.818 & 0.415 \\
\hline P2 <-Perceive... & 0.297 & 0.264 & & 0.162 & 1.834 & 0.070 \\
\hline P3 <- Perceive... & 0.393 & 0.368 & & 0.160 & 2.463 & 0.015 \\
\hline P4 <- Perceive... & 0.363 & 0.363 & & 0.110 & 3.309 & 0.001 \\
\hline P5 <- Perceive... & 0.335 & 0.285 & & 0.147 & 2.281 & 0.025 \\
\hline S1 <- Subjectiv... & 0.605 & 0.564 & & 0.165 & 3.662 & 0.000 \\
\hline$\$ 2<-$ Subjectiv... & 0.403 & 0.407 & & 0.167 & 2.415 & 0.018 \\
\hline S4 <- Subjectiv... & 0.497 & 0.470 & & 0.142 & 3.489 & 0.001 \\
\hline
\end{tabular}

Berdasarkan Tabel 7 di atas

diketahui bahwa:

1. Indikator Al, A4 dan A5 kurang baik dalam memprediksi Attitude karena mempunyai $\mathrm{p}$-value lebih besar dari 0.05 .

2. Indikator Bl dan B5 kurang baik dalam memprediksi Behavioral Intention karena mempunyai $\mathrm{p}$-value lebih besar dari 0.05 .

3. Indikator Pl dan P2 kurang baik dalam memprediksi Perceived Behavioral Control karena mempunyai p-value lebih besar dari 0.05 .
4. Adapun indikator-indikator dengan pvalue lebih kecil dari 0,05 dapat dengan baik memprediksi masingmasing varibelnya.

\subsubsection{Hasil Uji Multikolinearitas}

Seluruh indikator dalam outer model maupun dalam inner model harus dilakukan pengujian multikolineritas, hasil pengujiannya dapat dilihat pada Tabel 4.5 berikut: 
Tabel 8 Hasil Uji Multikolinearitas

Collinearity Statistics (VIF)

\begin{tabular}{|c|c|c|}
\hline \multirow[t]{2}{*}{ 园 } & Outer VIF Values & Inner VIF Values \\
\hline & & VIF \\
\hline A1 & & 1.015 \\
\hline A4 & & 1.048 \\
\hline A5 & & 1.042 \\
\hline B1 & & 1.438 \\
\hline$B 2$ & & 1.569 \\
\hline$B 3$ & & 1.117 \\
\hline B4 & & 1.129 \\
\hline B5 & & 1.155 \\
\hline$B 6$ & & 1.357 \\
\hline P1 & & 1.234 \\
\hline P2 & & 1.656 \\
\hline P3 & & 1.459 \\
\hline P4 & & 1.625 \\
\hline P5 & & 1.473 \\
\hline$\$ 1$ & & 1.035 \\
\hline$\$ 2$ & & 1.093 \\
\hline$\$ 4$ & & 1.128 \\
\hline
\end{tabular}

Berdasarkan tabel di atas nilai VIF untuk keseluruhan model tidak ada yang berada di bawah angka 10. Hal ini menandakan bahwa semua indikator pada outer dan inner model bebas multikolinearitas, karena tidak ada variabel yang berkorelasi kuat dengan variabel lainnya sehingga mempunyai kekuatan handal dan stabil dalam memprediksi.
Collinearity Statistics (VIF)

\begin{tabular}{|c|c|c|c|c|c|}
\hline \multirow[t]{2}{*}{ Outer VIF Value } & \multicolumn{2}{|c|}{ Inner VIF Values } & & & \\
\hline & Attitude & Behav & ral Inte... & Perceived Beh... & Subjective Nor... \\
\hline Attitude & & & 1.174 & & \\
\hline Behavioral Inte... & & & & & \\
\hline Perceived Beha... & & & 1.387 & & \\
\hline Subjective Nor... & & & 1.393 & & \\
\hline
\end{tabular}




\section{Tabel 9 Path Coefficient Pengaruh Attitude, Subjective Norms dan Perceiverd Behavioral Control terhadap Behavioral Intention.}

Path Coefficients

\begin{tabular}{|r|r|r|r|r|r|r|}
\hline & Mean, STDEV, T-Values, P-Val... & Confidence Intervals & Confidence Intervals Bias Co... & Samples \\
\hline & Original Sampl... & Sample Mean (... & Standard Devia... & T Statistics (|O/... & P Values \\
\hline Attitude -> Be... & 0.039 & 0.109 & 0.106 & 0.367 & 0.714 \\
\hline Perceived Beha... & 0.252 & 0.298 & 0.156 & 1.615 & 0.109 \\
\hline Subjective Nor... & 0.369 & 0.335 & 0.148 & 2.495 & 0.014 \\
\hline
\end{tabular}

Berdasarkan tabel di atas diketahui bahwa hanya variabel subjective norms yang mempunyai p-value dibawah 0.05. Oleh karena itu dapat diartikan bahwa variabel behavioral intention dipengaruhi oleh variabel subjective norms sebesar
0,369 satuan. Dimana setiap kenaikan satu satuan subjevtive norms dapat menaikkan 0.369 satuan behavioral intention.

Analisis R square dapat dilihat pada Tabel 4.7 berikut:

\section{R Square}

\section{Tabel 10 Koefisien Determinasi $\left(\mathrm{R}^{2}\right)$}

\begin{tabular}{|c|c|c|c|c|}
\hline \multirow[t]{2}{*}{ Matrix } & 掉音 & R Square & \multicolumn{2}{|c|}{ 接辛 R Square Adjusted } \\
\hline & & & R Square & R Square Adjus... \\
\hline \multicolumn{2}{|c|}{ Behavioral Inte... } & & 0.310 & 0.288 \\
\hline
\end{tabular}

Berdasarkan Tabel 4.7 di atas maka besarnya $\mathrm{R}^{2}$ adalah 0.310 atau 31 persen. Hal tersebut berarti varibel behavioral Intenttion dapat dijelaskan sebesar 31 persen oleh variabel attitude, subjective norm dan perceived behavioral.

\section{Kesimpulan dan Saran}

5.1 Simpulan

Simpulan yang dihasilkan dari penelitian ini akan menjawab pertanyaan penelitian yang diajukan yaitu:
1. attitude tidak memengaruhi niat mengonsumsi makanan dan minuman halal pada remaja.

2. subjective norms memengaruhi niat mengonsumsi makanan dan minuman halal pada remaja.

3. perceived behavioral control tidak memengaruhi niat mengonsumsi makanan dan minuman halal pada remaja. 


\subsection{Saran}

Berdasarkan simpulan di atas maka saran yang diajukan adalah:

1. Variabel yang berpengaruh adalah variabel subjective norms, yang merupakan pengaruh dari luar diri seseorang sehingga sosialisasi, kampanye (ajakan), promosi serta pendidikan tentang kehalalan suatu produk baik makanan maupun minuman terus ditingkatkan terutama dengan konten yang didesain sedemikian rupa sehingga menarik dan sesuai dengan para remaja.

2. Menambah jumlah sampel tidak.

3. Menambah variabel tambahan yang memperluas TPB.

\section{Daftar Pustaka}

Al-Quran

Batubara, Jose RL. 2010. Adolescent Development (Perkembangan Remaja). Sari Pediatri, Vol. 12, No. 1, Juni 2010. Http://Www.Idai.Or.Id/Artikel/Se putar-Kesehatan-Anak/KesehatanReproduksi-Remaja-Dalam-Aspek$\underline{\text { Sosial. }}$

Briliana, V., \& Mursito, N. 2017. Exploring Antecedents and Consequences of Indonesian Muslim Youths' Attitude Towards Halal Cosmetic Products: A Case Study in Jakarta. Asia Pacific Management Review. http://dx.doi.org/10.1016/j.apmrv.20 $\underline{17.07 .012}$

Fordebi Dan Adesy, Dewan Pengurus Nasional. 2016. Ekonomi Dan Bisnis Islam: Seri Konsep Dan Aplikasi Ekonomi Dan Bisnis Islam. PT Rajagrafindo Persada. Jakarta.

Hosking, Alan. 2018. Change Your Retirement Age-Part 1-More to Life. HR Future, Volume 2018 Number 2, Feb 2018, p. $48-48$.

https://Jakarta.Bps.Go.Id/Statictable/2017/ 01/30/142/Jumlah-PendudukMenurut-Kelompok-Umur-DanJenis-Kelamin-Di-Provinsi-DkiJakarta-2015.Html. Diakses Tanggal 31 Maret 2019

https://Kbbi.Web.Id/Halal. Diakses Tanggal 31 Maret 2019

https://Kbbi.Web.Id/Persepsi Diakses Tanggal 31 Maret 2019

https://Www.Bi.Go.Id/Id/RuangMedia/InfoTerbaru/Pages/PengembanganIndustri-Halal-DukungPertumbuhan-Ekonomi- 
Nasional.Aspx. Diakses Tanggal 31 Maret 2019

https://Www.Dakwatuna.Com/2015/06/0 3/69647/Ternyata-Alquran-BicaraBanyak-TentangRemaja/\#Axzz5jh7whfcz. Diakses Tanggal 31 Maret 2019

Khalek, Aiedah Abdul and Ismail, Sharifah Hayaati Syed. 2015. Why Are We Eating Halal - Using the Theory of Planned Behavior in Predicting Halal Food Consumption among Generation Y in Malaysia. International Journal of Social Science and Humanity, Vol. 5, No. 7, July 2015.

Malau, Waston; Simanjuntak, Daniel Harapan Parlindungan. 2017. Pemuda dan Masa Depan Bangsa. Prosiding Seminar Nasional Tahunan Fakultas Ilmu Sosial Universitas Negeri Medan Tahun 2017 Vol. 1 No. 1 2017, Hal. 30-33. Http://Semnastafis.Unimed.ac.id

Nnamdi, Madichie. 2012. Consumer Perception: Book Chapter. Https:/Www.Researchgate.Net/P ublication/328676646 Consumer P erception

Rochmanto, Bayu Al; Widiyanto, Ibnu. 2015. Pengaruh Pengetahuan Produk dan Norma Religius Terhadap Sikap Konsumen dalam Niat Mengkonsumsi Produk Makanan dan Minuman Halal (Studi Kasus di Kota Semarang). Diponegoro Journal Of Accounting Volume 4, Nomor 1, Tahun 2015, Halaman 2.

www.depkes.go.id. Infodatin. Diakses Tanggal 31 Maret 2019

Vanany, Iwan; Soon, Jan Mei; Maryani, Anny dan Wibawa, Berto Mulia. 2019. Determinants of Halal-Food
Consumption In Indonesia. Journal of Islamic Marketing. Emerald Publishing Limited. DOI 10.1108/JIMA-09-2018-0177

Yuswohady. (2014). Marketing to The Middle Class Muslim - Kenali Perubahannya, Pahami Perilakunya, Petakan Strateginya. Penerbit Gramedia Pustaka Utama. Jakarta.

Perusahaan yang Terdaftar di ISSI. Artikel Ilmiah , 1-14.

Suharyadi, \& Purwanto. (2013). Statistika untuk Ekonomi dan Keuangan Modern. Jakarta: Salemba Empat.

Sujarweni, W. (2014). SPSS Untuk Penelitian. Yogyakarta: Pustaka baru Press.

Sutendi, A. (2011). Pasar Modal Syariah. Jakarta: Sinar Grafika Ofset.

Widyasa, V. I., \& Worokinasih, S. (2018). Pengaruh Tingkat Inflasi, Nilai Tukar Rupiah, dan Tingkat Suku Bunga Domestik Terhadap Indeks Saham Syariah Indonesia (ISSI). Jurnal Administrasi Bisnis, 119-128. 